\title{
Cloning, expression, purification and characterization of replication protein from plasmid pGP2 from Acetobacter estunensis
}

\author{
Peter Grones, Jozef Grones
}

Comenius University, Department of Molecular Biology, Mlynska dolina B2, 84215 Bratislava 4, Slovak Republic.

Email: grones@,fns.uniba.sk

Received 10 September 2010; revised 22 October 2010; accepted 8 November 2010.

\begin{abstract}
The Acetobacter estunensis Rep $_{34}$ protein participates in the replication of bacterial plasmid pGP2. The $\operatorname{Rep}_{34}$ protein of the $A$. estunensis, was cloned to the expression vector, that ensure fusion with a His-tag sequence ( $\operatorname{Rep}_{34}$ His-tagged), over-expressed in Escherichia coli and purified by metal-affinity chromatography to yield a highly purified and active protein. On this purified protein number different activities and motifs were detected. DNA band-shift assays showed that the $\operatorname{Rep}_{34}$ His-tagged protein bound to the regulation region for replication on the linear double-stranded DNA. In the protein was determined phosphatase activity, ATPase activity and protein is possible to unwind double strand DNA.
\end{abstract}

Keywords: Acetobacter Estunensis; Rep ${ }_{34}$ Protein; DNA-Binding Activity; ATPase Activity; Phosphatase Activity; Unwinding Activity

The replication of eukaryotic and prokaryotic chromosomes, bacteriophages and bacterial plasmids DNA involves several analogous events and similarities in replisome architecture. Many systems have specific initiation proteins, including bacterial DnaA protein, phage lambda $\mathrm{O}$ protein, plasmid replication initiation proteins (Rep) and the eukaryotic origin recognition complex (ORC). The specific mechanism for replication initiation of a given replicon is dependent on both the structure of the replication origin and the nature of the replication initiation protein. The replication of bacterial extra-chromosomal replicons, such as plasmids or phages is generally limited to a single host or a few closely related host's proteins [1]. Replication proteins generally initiates and regulates bacterial chromosome or plasmid replication and serves as a transcription factor [2,3].

The origins of prokaryotic and some eukaryotic repli- cons possess characteristic functional elements, includeing specific binding sites for the appropriate initiation protein and an AT-rich region where DNA duplex destabilization occurs. Plasmid origins usually contain multiple binding sites (iterons) for the plasmid-specific replication initiation protein as well as one or more binding sites for the host replication initiation protein, DnaA (DnaA boxes) [1]. These proteins interact with repeated regulation sequences. They also interact with Rep protein or DnaA protein on regulation boxes, which are located within the ori regions or the promoter regions or intergenic regions of many bacterial chromosomes and plasmids [4].

The structural elements of the origin are employed for broad-host-range plasmid replication and maintenance in different host bacteria species. For example, the minimal origin of the broad-host-range plasmid RK2 possesses five iterons and is functional in E. coli. However, the presence of three iterons stabilizes RK2 plasmid maintenance in Pseudomonas putida [5]. In addition, the region with four DnaA boxes is essential for RK2 replication in E. coli, but is dispensable for replication of the plasmid in Pseudomonas aeruginosa [6,7].

In the $E$. coli chromosome, the replication origin (oriC) contains five DnaA box sequences. The binding of multiple DnaA molecules in the presence of the histone-like $\mathrm{HU}$ protein and the site-specific DNA-binding protein IHF (integration host factor) results in destabilization of the duplex DNA within the nearby AT-rich sequences of the oriC of E. coli [3]. Origin opening of the narrowhost-range plasmids $\mathrm{pSC} 101, \mathrm{~F}, \mathrm{P} 1$, and $\mathrm{R} 6 \mathrm{~K}$ requires, in addition to $E$. coli DnaA, HU and/or IHF proteins, the binding of plasmid-encoded replication initiation proteins [8-12]. Similarly, the formation of an open complex at the replication origin of the broad-host-range plasmid RK2 by the plasmid encoded TrfA initiation protein requires $E$. coli $\mathrm{HU}$, and is stabilized by E. coli DnaA [13].

In contrast to the chromosomal oriC, plasmid origins 
do not require ATP for open complex formation [8-10]. A basis for this lack of dependence on ATP, induced in an ATP-independent mode, by the complex of the plasmid-encoded Rep protein and the host HU or IHF $[9,14,15]$.

Plasmids encoded systems that control their replication such that fairly precise, steady-state copy numbers are maintained [16]. Plasmid replicons from Gramnegative bacteria always seem to encode a negative feedback control system. Two basic mechanisms for the regulation of plasmid replication have been recognized so far: one operates via an antisense RNA transcript that negatively regulates the replication; the other operates via iterons, a series of direct repeat sequence located within ori that intereract with iteron-binding Rep proteins are responsible for both the initiation of replication and its control $[16,17]$.

From acetic acid bacteria were purified and characterised several DNA plasmids which encoded rep gene which product is able to regulate replication process. The first identified cryptic plasmid from Acetobacter encoding Rep protein had been used for the construction of cloning vectors $[18,19]$. Later from Acetobacter pasteurianus was identified large plasmid pAC1 [20], and pAP12875 [21]. From Gluconobacter was isolated plasmid pJK2-1 [22], and from A. aceti plasmid pAG20 [23].

In this paper we presented replication protein of plasmid pGP2 isolated from Acetobacter estunensis GP2 strain and characterise main activities that belong to the bacterial replication proteins.

\section{MATERIALS AND METHODS}

\subsection{Bacterial Strains and Cultivation Media}

Escherichia coli strain XL1 Blue (tetracycline ${ }^{\mathrm{R}}$ ) [24] was used for plasmid isolation and for cloning DNA fragments and strain BL21 (DE3) $\left[F^{-}\right.$ompT gal dcm lon hsd $S_{B}\left(r_{B}{ }^{-} m_{B}{ }^{-}\right) \lambda(\mathrm{DE} 3$ [lacI lacUV5-T7 genel indl sam7 nin5]) was used as a host for protein expression. The pGP2 plasmid isolated from Acetobacter estunensis GP2 used as template for rep $_{34}$ gene. Acetobacter strain was cultivated in YPG medium (5\% yeast extract, 3\% peptone, and $1 \%$ manitol) and E. coli strain on LB medium ( $10 \%$ Tryptone, $5 \%$ yeast extract and $5 \% \mathrm{NaCl} \mathrm{pH} \mathrm{7.4)}$ supplemented with $50 \mu \mathrm{g} / \mathrm{ml}$ kanamycin and $100 \mu \mathrm{g} / \mathrm{ml}$ ampicillin.

\subsection{Biochemical Material}

The reagents for PCR and oligonucleotide primers were obtained from Invitrogen Life Technologies (Carlsbad, CA, USA). The bacterial vector pGEM-T Easy (ampicillin $^{\mathrm{R}}$; Promega, Madison, WI, USA) expression pET-
$28 \mathrm{a}+$ vector (T7 promoter, kanamycin ${ }^{\mathrm{R}}$; Novagen, Madison, WI, USA), was used for cloning and expression rep gene. Restriction endonucleases, isopropylthio- $\beta$-Dgalactopyranoside (IPTG), and T4 DNA ligase were obtained from BioLabs. $p$-nitrophenyl phosphate (pNPP) and protein standard used as SDS-PAGE marker were from Sigma Chemical (St. Louis, MO, USA).

\subsection{Cloning and Expression Vector Construction}

Recombinant DNA techniques were performed using conventional protocols. The rep 34 gene of Acetobacter estunensis (ORF2) was amplified using: forward 5'-GGA TCC ATG TGG TAT CAA AAG ACG CT-3 and reverse primer $5^{\prime}$-AAG CTT TTA TTC AGA TGG CGG CTT G-3'. The amplified DNA encoding the rep 34 gene produced a fragment of around $627 \mathrm{bp}$ was cloned into pGEM-T Easy vector and transformed in E. coli XL1. Selected construct pGEM-rep 34 was sequenced by dideoxy chain termination method [25] using an ABI Prism 3200 automated DNA sequencer (Applied Biosystems, Foster City, CA, USA). Sequenced data were analyzed using BLAST-Basic local alignment search tools program [26] through the network service of the National Center for Biotechnology Information (http:// ww.ncbi.nlm.nih.gov).

The DNA encoding the rep $_{34}$ was then sub-cloned into vector $\mathrm{pET}-28 \mathrm{a}-$ in BamHI and HindIII sites which was used to transform $E$. coli XL1. The new vector construct was named $\mathrm{pET}-$ rep $_{34}$. Sequencing of the cloned vectors revealed the open reading frame (ORF2) of the rep 34 gene plus the expected 32 additional amino acid residues derived from pET-28a- vector at its amino terminus (MGSSHHHHHHSSGLVPRGSH MASMTGGEEMGR), including the cluster of six histidine residues for protein purification by metal affinity chromatography. The expression vector $\mathrm{pET}-$ rep $_{34}$ was extracted from the transformants using JETQuick Plasmid kit (Genomed), and used to transform to $E$. coli BL21 (DE3) competent cells. Selected transformant $\mathrm{pET}-28$-rep 34 was used for protein expression and purification.

\subsection{Expression and Purification of Recombinant $\operatorname{Rep}_{34}$}

A total of $100 \mu$ of an overnight culture of $E$. coli BL21 (DE3) with pET-28-rep 34 was diluted into $100 \mathrm{ml}$ of LB medium containing kanamycin $(50 \mu \mathrm{g} / \mathrm{ml})$. The culture was grown at $37^{\circ} \mathrm{C}$ until optical density at $590 \mathrm{~nm}$ reached 0.6 and was induced with $0.5 \mathrm{mM}$ IPTG. The incubation continued for an additional $2 \mathrm{~h}$ in the same temperature. After incubation, the culture was harvested by centrifugation at $8,000 \mathrm{~g}$ for $10 \mathrm{~min}$ at $4^{\circ} \mathrm{C}$. The pellet cells were suspended in $25 \mathrm{mM}$ Tris. $\mathrm{HCl}$, pH 8.0 buffer 
containing $20 \mathrm{mM} \mathrm{NaCl}$, and $5 \%$ glycerol and disrupted for $10 \mathrm{~min}$ at $4^{\circ} \mathrm{C}$ followed by sonication. The suspendsion was then centrifuged at $16,000 \mathrm{~g}$ for $10 \mathrm{~min}$ at $4^{\circ} \mathrm{C}$ to separate the cell debris, and the solubility of the recombinant fusion protein was analyzed by $12 \%$ SDSPAGE. The soluble fraction containing recombinant pET-rep 34 was loaded onto a Ni-NTA column (Qiagen, Hilden, Germany) pre-equilibrated with $50 \mathrm{mM}$ sodium phosphate, $\mathrm{pH} 8.0$ buffer containing $300 \mathrm{mM} \mathrm{NaCl}$ and $10 \mathrm{mM}$ imidasole. The unbound proteins were washed out with the same buffer used for equilibration of the column. Subsequently, the recombinant proteins were eluted with the same buffer containing 50 to $250 \mathrm{mM}$ imidazole. The resulting pET-rep ${ }_{34}$ was exhaustively dialyzed in $50 \mathrm{mM}$ Tris. $\mathrm{HCl}$, pH 8.0 buffer containing $50 \mathrm{mM} \mathrm{NaCl}$ for elimination of imidazole. The protein purity was confirmed by the presence of a single band on SDS-PAGE $12 \%$ of molecular weight predicted for the $\mathrm{Rep}_{34}$ (about $25.5 \mathrm{kDa}$, with His-tag). For protein visualization, the gels were stained with Coomassie Brilliant Blue G-250 (Bio-Rad Laboratories) and distained with $10 \%$ acetic acid and $20 \%$ methanol. The purified protein was frozen and stored at $-80^{\circ} \mathrm{C}$. Protein concentration recombinant soluble protein concentration was determined by UV absorbance at $280 \mathrm{~nm}$ (Spectrophotometer ND-1000 UV-Vis, NanoDrop Technologies).

\subsection{Computational Methods for Secondary Structure Prediction}

The DNA nucleotide sequence was translated into a protein sequence and the deduced amino acid sequence was analyzed using the Expasy SwissProt Web server (http://www.expasy.ch). The sequence of amino acids from $\mathrm{Rep}_{34}$ was aligned with 45 sequences of GST enzymes using ClustalW [27]. The methods used for general secondary- structure prediction were Jpred [28], PHD [29], PSIPRED [30], and SSpro [31]. The predicttion of secondary structure and analysion of protein motifs were made using program CLC Main Workbench 5.1 .

\subsection{Assay of ATPase Activity}

The ATPase activity was assayed by using non radioactive modified method [32]. With interaction of free anorganic phosphate with fresh prepared $0.045 \%(\mathrm{w} / \mathrm{v})$ malachit green and $4.2 \%(\mathrm{w} / \mathrm{v})$ molibden ammonium in $4 \mathrm{M} \mathrm{HCl}$ in the rate of $3: 1$. Reaction mixture contained in $50 \mu \mathrm{l}(1 \mu \mathrm{g}$ protein, $50 \mathrm{mM}$ Tris- $\mathrm{HCl} \mathrm{pH} 7.9,5 \mathrm{mM}$ $\mathrm{MgCl}_{2}$ and $1 \mathrm{mM} \mathrm{ATP}$ ) at $37^{\circ} \mathrm{C}$ in times volume $0,5,10$, 15, $20 \mathrm{~min}$. After reference times was added $800 \mu \mathrm{l}$ malachit-molybdene solution and after 1 min added 100 $\mu 1$ of $34 \%(\mathrm{v} / \mathrm{v})$ sodium citrate and the absorbance change was measured spectrophotometrically at $660 \mathrm{~nm}$.
As a standard was used reaction with different concentration of $\mathrm{Na}_{3} \mathrm{PO}_{4}$.

\subsection{Helicase Assay}

Helicase activity was detected by the release of a Fam3labeled oligonucleotide annealed to M13mp18 singlestranded (ss) DNA [33]. The oligonucleotide, which consisted of 20 bases $\left(5^{\prime}\right.$ - fam3-GTT GTA AAA CGA CGG CCA GT $-3^{\prime}$ ) was complementary to the M13 DNA. Labeled oligonucleotide was annealed with M13 ss DNA (New England BioLabs) in $10 \mathrm{mM}$ Tris. $\mathrm{HCl}(\mathrm{pH}$ 8.0), $1 \mathrm{mM}$ EDTA, and $100 \mathrm{mM} \mathrm{NaCl}$, heat for $5 \mathrm{~min}$ at $65^{\circ} \mathrm{C}$ and slowly cooling down for $30 \mathrm{~min}$ to room temperature. The double-strand (ds) substrate was purified by ethanol precipitation to remove unannealed oligonucleotide. The helicase reaction mixture contained $5 \mathrm{nM}$ substrate in $20 \mathrm{mM}$ Tris.HCl, $2 \mathrm{mM}$ DTT, $5 \mathrm{mM} \mathrm{MgCl}$, $5 \%$ glycerol, $5 \mathrm{mM}$ ATP, $0.1 \mathrm{mg} / \mathrm{ml} \mathrm{BSA}$, and the solution was adjusted to $\mathrm{pH}$ 7.5. The reactions were incubated at $37^{\circ} \mathrm{C}$ for $30 \mathrm{~min}$ and stopped adding $1 / 10 \mathrm{vol}-$ ume of $3 \mathrm{M}$ sodium acetate and ethanol precipitate. After precipitate pellet was suspended in $100 \mu 1$ of sterile water and unwound ds DNA substrate was quantified by fluorometric analysis at $492 \mathrm{~nm}$ on fluorescence analyzer (Tecan Safire 2 Microplate Fluorescence Reader). DNA unwinding was calculated as a percentage of the total counts in each reaction.

\subsection{Gel mobility Shift Assays}

The DNA probe for the electrophoretic mobility shift assay (EMSA) was the plasmid pGP2 transcription and replication region in position 1671-2761 bp. The probe was synthesized by PCR, using the primers 5' - GAG CTC ATG CAT GTA CGC CGC GGT - 3' and 5' - AAG CTT TTA TTC AGA TGG CGG CTT G - 3'. After amplification, the DNA probe was cleaved by PvuII which created two fragments 539 and 475 bp. Mobility shifts were performed as previously described [34], with some modifications. The reaction mixtures $(15 \mu \mathrm{l})$ contained $50 \mathrm{mM}$ Tris. $\mathrm{HCl}$ (pH 8.0), $50 \mathrm{mM} \mathrm{NaCl}, 4.8 \mathrm{mM}$ dithiothreitol, $1.0 \mathrm{mg} / \mathrm{ml}$ bovine serum albumin per $\mathrm{ml}$ and $20 \%(\mathrm{w} / \mathrm{v})$ glycerol. DNA probe, reaction mixture and recombinant Rep34 protein $(0.4 \mathrm{pmol})$ were incubated at $30^{\circ} \mathrm{C}$ for $15 \mathrm{~min}$. The separation take place on a $4 \%$ polyacrylamide gel containing $0.09 \%$ bis-acrylamide, $2.5 \%$ glycerol, and $1 \times \mathrm{TBE}$ at $5-10 \mathrm{~V} / \mathrm{cm}$. The complexes were visualized after colored ethidium bromide [35].

\subsection{Phosphatase Activity}

The enzymatic activity of $\mathrm{Rep}_{34}$ towards $p$-nitrophenyl phosphate (pNPP) substrate was assayed at $37^{\circ} \mathrm{C}$ by spectrophotometric detection of the absorbance at 405 $\mathrm{nm}$ due to the release of $p$-nitrophenol (pNP) [36]. 
Kinetic measurements assigned to determine substrate kinetic parameters were performed in reaction mixtures of a total volume of $400 \mu \mathrm{l}$. The mixtures contained 50 $\mathrm{mM}$ Tris-acetate, $\mathrm{pH} 5.5,50-100 \mathrm{nM} \mathrm{Rep}_{34}$, in the presence or absence of $10 \mathrm{mM} \mathrm{MgCl}_{2}$, and different concentrations of $\mathrm{pNPP}$. The reactions were initiated by the addition of the enzyme, and quenched after $10 \mathrm{~min}$ by the addition of $100 \mu \mathrm{l}$ of $2 \mathrm{M} \mathrm{NaOH}$ followed by centrifugation at $14,000 \mathrm{~g}$ for $5 \mathrm{~min}$. The absorbance at $405 \mathrm{~nm}$ was read for supernatants of reaction mixtures (containing enzyme) and controls (the same substrate concentration omitting the enzyme), and the difference between these measurements represented the real rate of product formation.

\subsection{Protein Analysis}

Proteins were analyzed by SDS-PAGE [37] stained either by Coomassie Brilliant Blue R-250 method. Protein concentrations were determined by the Bradford procedure [38] or by densitometric analyses of Coomassie Brilliant Blue-stained SDS-PAGE gels. Bovine serum albumin (BSA) was used as the standard.

\section{RESULTS AND DISCUSSION}

Bacterial plasmid pGP2 purified from Acetobacter estunensis GP2 (2 797 bp) encoded three proteins. ORF2 encoded 209 aa large protein belonging to group of replication protein designed as $\operatorname{Rep}_{34}$ (Figure 1). By the analysis of amino acid sequence were determined the number of alpha helixes (4 larger than 4 aa) and beta structures (4 larger than 4 aa) and two domains: Helicase conserved C-terminal domain (137-175 aa) and HTH motive (169-203 aa). Isoelectric point of this protein, determined at pI 9.25, is similar to the isoelectric point determined in replication proteins of plasmid pAG20 from $A$. aceti 3620 (pI 8.2) [23], but a bit distinct to isoelectric point of protein from pAP12875 plasmid from A. pasteurianus (pI 12.1) [21].

The rep gene was amplified using PCR amplification and this product was cloned into pGEM-T easy vector (pGEM-rep ${ }_{34}$ recombinant). Re-cloning gene in pET28aexpression vector was in E. coli BL21 (DE3) cells amplified protein under $\mathrm{T} 7$ promoter and was constructed pET28-rep 34 .

\subsection{Protein Purification}

The expression vector containing the encoding rep $_{34}$ gene was used to transform to E. coli BL21 (DE3) cells, which over expressed a Rep ${ }_{34}$ protein after IPTG induction. An over-expressed band on SDS-PAGE corresponding to a protein of approximately $25.55 \mathrm{kDa}$ (with His-tag) was observed in the crude bacterial lysates, consistent with that expected for the recombinant protein
(Figure 2(a)). The greater part of $\operatorname{Rep}_{34}$ was found in the supernatant after lysis and after using affinity chromatography, the recombinant protein was quickly purified to apparent homogeneity (Figure 2(b)). More detailed data and purification steps were presented in Table 1. The total protein yield at the last purification step was approximately $71 \mathrm{mg}$ of $\mathrm{Rep}_{34}$ per liter of bacterial culture.

Upon SDS-PAGE under reducing conditions, the isolated protein migrated as a large homogenous band with a molecular weight between 20 and $30 \mathrm{kDa}$, consistent with that expected for a Rep 34 monomer. A monomer of the recombinant protein has a predicted molecular weight of approximately $23.31 \mathrm{kDa}$. The molecular mass of Rep34 is lower than the molecular mass of RepA monomer protein described in plasmid pRSF1010 that was determined on $31 \mathrm{kDa}$ [39]. The results of the secondary-structure prediction indicate that overall $\mathrm{Rep}_{34}$ is composed of the same amount of $\alpha$-helical and $\beta$-sheet conformation.

\subsection{In Vitro DNA-Binding Activity}

DNA band-shift assays showed that the purified Rep $_{34}$ His-tagged protein was able to bind specifically to linear double-stranded amplified $1091 \mathrm{bp}$ fragment from replication region of plasmid pGP2 in position 1670-2761 bp. PCR product was cleaved by PvuII and afford two fragments 475 bp and 539 bp which were used as substrate for gel shift assay. Incubation of increasing concentrations of $\mathrm{Rep}_{34}$ with a fixed amount of DNA progresssively altered the mobility of the DNA, indicating the formation of protein-DNA complexes. Since the $\mathrm{Rep}_{34}$ apparently has sequence specificity. Furthermore, the increase in DNA band retardation dependent on the $\mathrm{Rep}_{34}$ protein concentration is probably due to the progressive occupation of the DNA molecule by $\operatorname{Rep}_{34}$ (Figure 3 lane 2-6).

Interaction $\mathrm{Rep}_{34}$ protein with substrate DNA was specific on the 539 bp large fragment encoded regulation region for transcription of replication protein as well as ori region of plasmid pGP2. The second smaller DNA fragment $475 \mathrm{bp}$ did not change its position during experiment and showed that it is not a specific substrate for analyzed protein.

\subsection{Assay of ATPase Activity}

The most of enzymes, that catalyse biomolecular reactions involving binding to the DNA and modificate its structure, need energy from ATP dissociation for their right functioning. ATP molecule can be dissociated by the supporting protein or by the enzyme itself. Rep $\mathrm{R}_{34}$ protein belongs to the second group and the ATPase ac- 


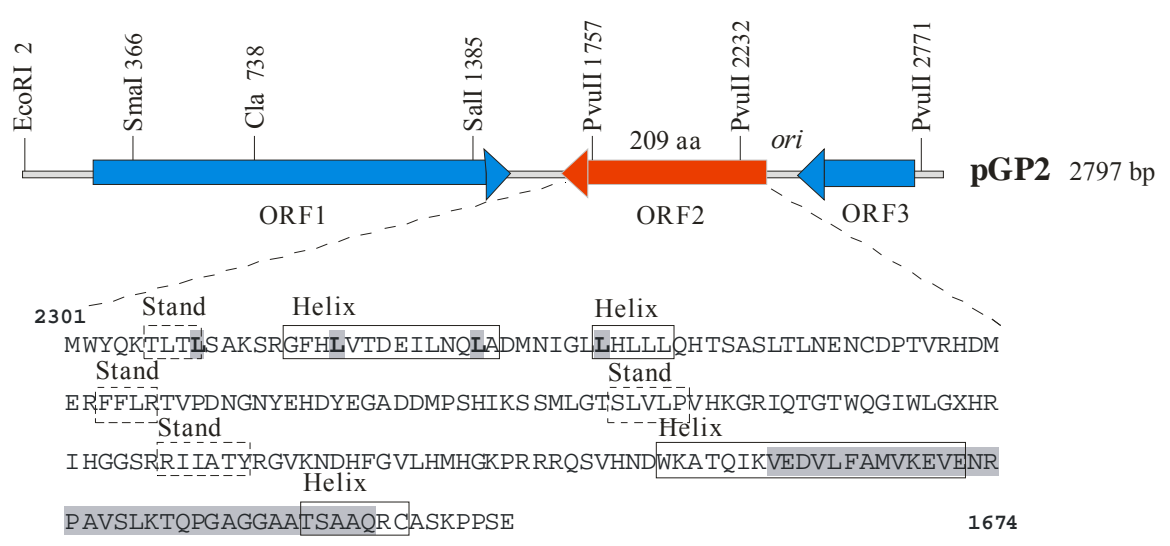

Figure 1. Genetic map of pGP2 plasmid from Acetobacter estunensis GP2. Replication protein encoded ORF2 (1674-2301 bp; 209 aa). Gray fraim determined HTH region in protein, full frames determined $\alpha$ helix and dashed frame determined $\beta$ structure of protein. The gray $\mathrm{L}$ represents amino acids residues leucine, that may form the structure of leucine zipper.

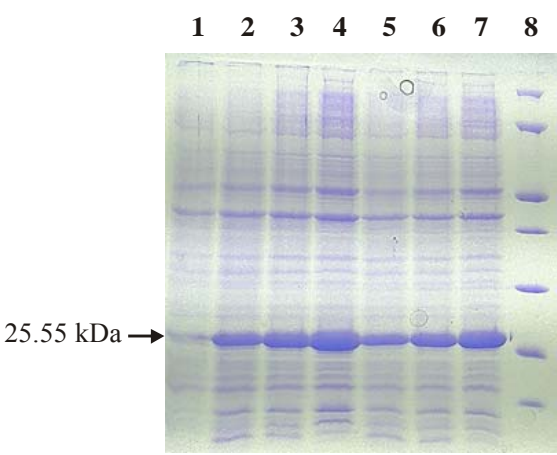

(a)

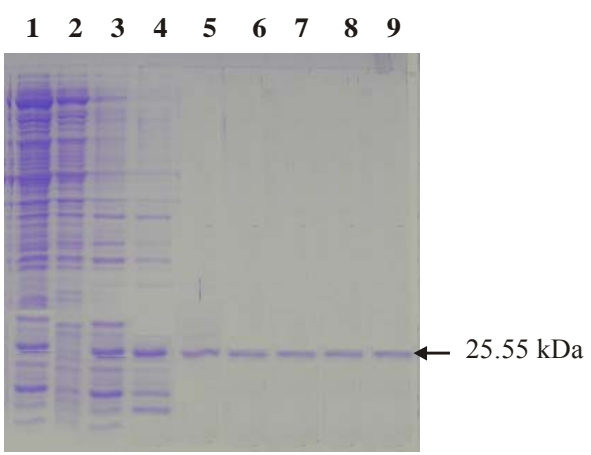

(b)

Figure 2. Rep $_{34}$ expression and purification. 12\% SDS-PAGE showing: (a) lane 8, molecular weight standard; lane 1, total proteins from cells culture before induction with IPTG; lanes 2-4, total proteins from cells after $0.5,1$, and $2 \mathrm{~h}$ of induction with IPTG $\left(0.5 \mathrm{mM}\right.$ IPTG at $\left.37^{\circ} \mathrm{C}\right)$, respectively, lanes 5-7, total proteins from cells after $0.5,1$, and $2 \mathrm{~h}$ of induction with IPTG $\left(0.5 \mathrm{mM}\right.$ IPTG at $\left.30^{\circ} \mathrm{C}\right)$. (b) lane 1 , exprimed protein loaded to column, lanes 2,3 washed column with $5 \mathrm{mM}$ imidazole, lane4-9 recombinant protein $\mathrm{Rep}_{34}$ eluted from Ni-NTA resin with $20 \mathrm{mM}, 40 \mathrm{mM}, 60 \mathrm{mM}, 80 \mathrm{mM}, 100 \mathrm{mM}$ and $250 \mathrm{mM}$ imidazole, respectively. The $\mathrm{Rep}_{34}$ bands are indicated by an arrow approximately $25.55 \mathrm{kDa}$ ).

Table 1. Purification of $\mathrm{Rep}_{34}$ protein after expression from Escherichia coli.

\begin{tabular}{cccccc}
\hline Procedure & Volume $(\mathrm{ml})$ & Protein $(\mathrm{mg})$ & $\begin{array}{c}\text { Protein } \\
\text { concentration } \\
(\mathrm{mg} / \mathrm{ml})\end{array}$ & Yield (\%) & $\begin{array}{c}\text { Fold } \\
\text { purification }\end{array}$ \\
\hline $\begin{array}{c}\text { sonification } \\
\begin{array}{c}\text { streptomycin } \\
\text { sulphate }\end{array}\end{array}$ & 5 & 271 & 54.2 & 100 & 1 \\
Ni-affi-Gel & 1 & 216 & 48 & 88 & 1.25 \\
\hline
\end{tabular}

Starting material was $0.5 \mathrm{~g}$ E. coli BL21 (DE3) cell paste

tivity was determined by standard modified method [32] by removing anorganic phosphate from ATP. As showed Figure 4, one microgram of protein converse about 0.58 $\pm 0.11 \mu \mathrm{g} / \mathrm{min}$ ATP to ADP. This activity is higher than the ATPase activity of SecA protein from E. coli $(0.32$ $\mu \mathrm{g} / \mathrm{min}$ ) [40], but similar to the products of rep genes from $E$. coli [41] and bacteriophages replication proteins [42]. 


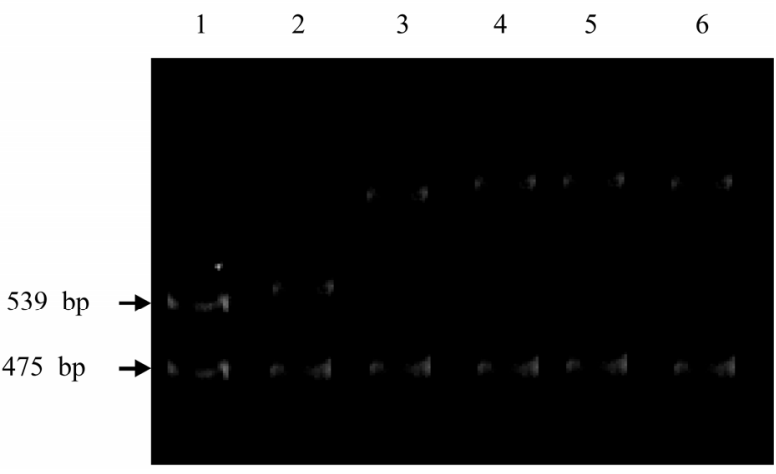

Figure 3. DNA-binding activity of the $\mathrm{Rep}_{34}$ His-tagged protein. The purified $\mathrm{Rep}_{34}$ His-tagged protein was analyzed for DNA-binding activity in band-shift assays using linear two fragments 475 and 539 bp of regulation region of pGP2 plasmid Samples were analyzed in $4 \%$ non denaturated PAGE in TBE buffer and visualized after ethidium bromide staining. The bands observed in lane 1 in the absence of added protein and lane 2-6 in presence of different concentration of binding protein $\left(0.1 \mu \mathrm{g}, 0.5 \mu \mathrm{g}, 1 \mu \mathrm{g}, 2 \mu \mathrm{g}\right.$, and $5 \mu \mathrm{g}$ of $\operatorname{Rep}_{34}$ protein).

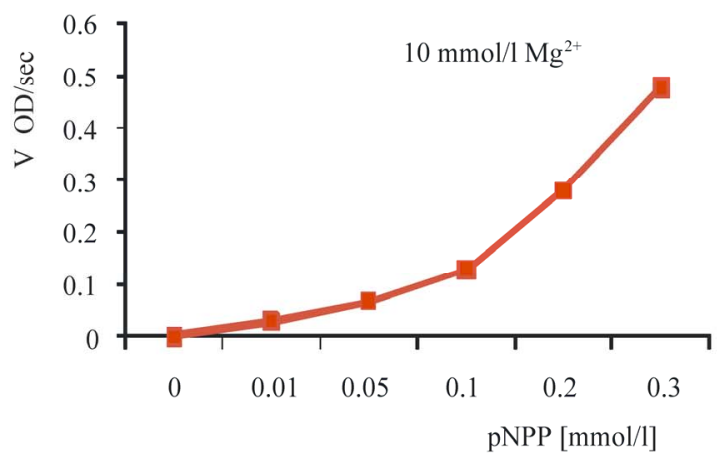

(a)

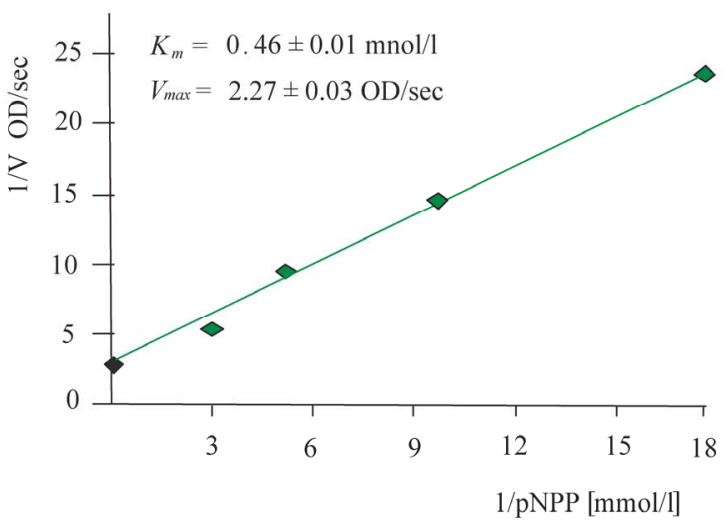

(c)

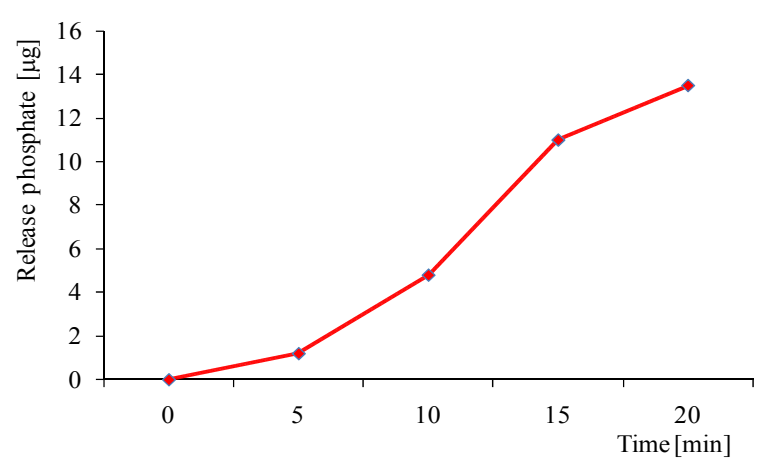

Figure 4. Determination of ATPase activity replication protein $\mathrm{Rep}_{34}$ from plasmid pGP2.

\subsection{Determination of Phosphatase Activity}

Catalytic activity of this protein was studied as an acidic phosphatase, since the highest activity was observed at pH 5.5. Thus, we analyzed the enzymatic activity of Rep $_{34}$ protein and determined the catalytic constants of

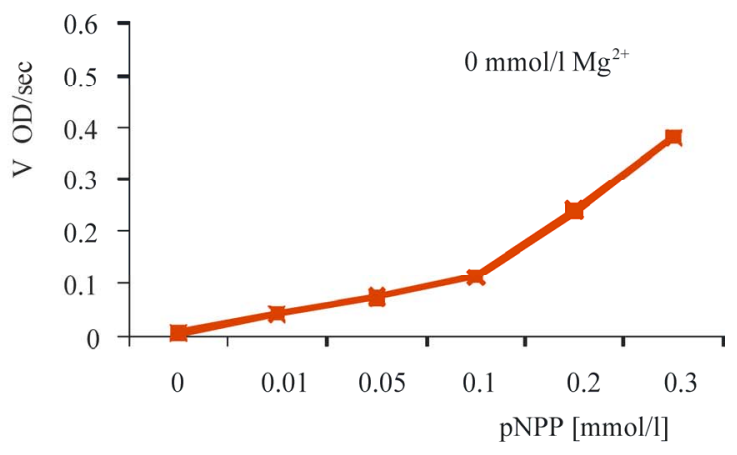

(b)

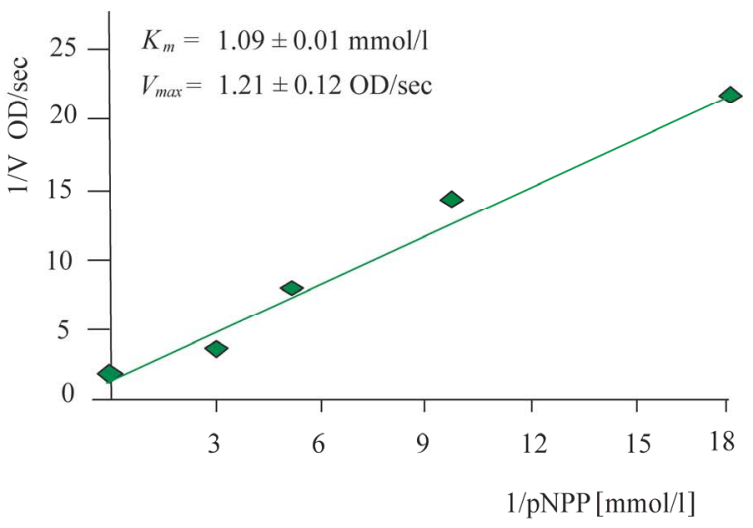

(d)

Figure 5. Enzymatic phosphatase activity $\mathrm{Rep}_{34}$ protein in the presence or absence of $10 \mathrm{mM} \mathrm{Mg}^{2+}$. (a) Standard Michaelis-Menten curve of $\operatorname{Rep}_{34}$ activity assayed with pNPP in the concentration range of $0.01-0.3 \mathrm{mM}$ in the buffer comprising $50 \mathrm{mM}$ Tris-acetate, $\mathrm{pH} 5.5,10 \mathrm{mM} \mathrm{MgCl}_{2}$. (b) Standard Michaelis-Menten curve of Rep 34 activity assayed with pNPP in the concentration range of 0.01-0.3 mM in the buffer comprising $50 \mathrm{mM}$ Tris-acetate, pH 5.5. (c) Lineweaver-Burk plot of the kinetic process presented in (a) was used to derive $K_{\mathrm{m}}$ and $V_{\max }$. (d) Lineweaver-Burk plot of the kinetic process presented in (b) was used to derive $K_{\mathrm{m}}$ and $V_{\max }$. 


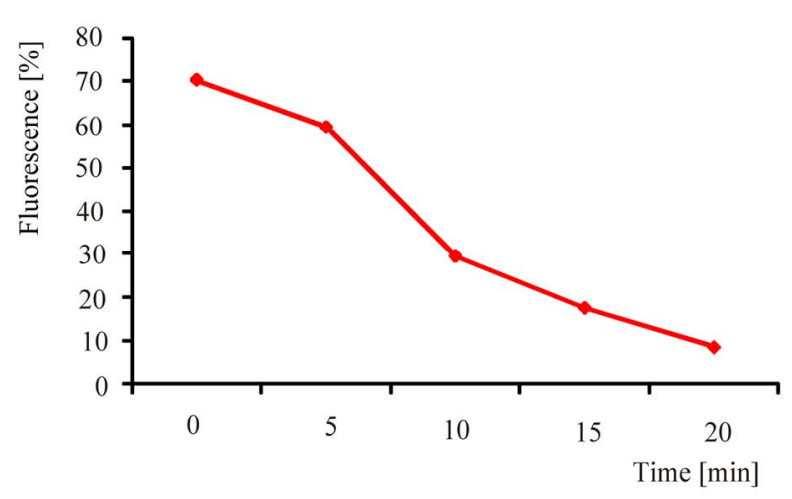

(a)

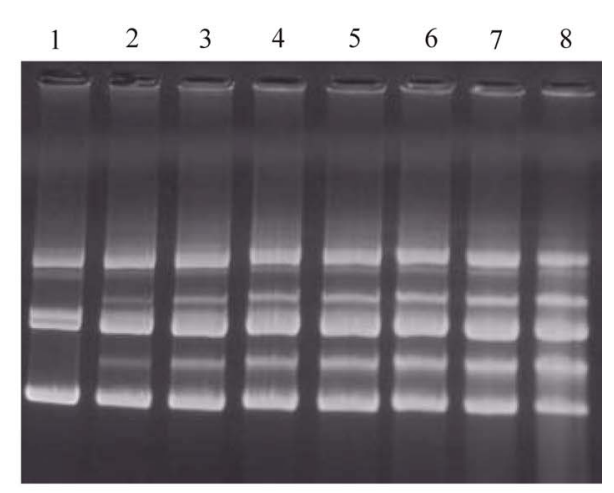

(b)

Figure 6. A representative DNA helicase assay in the presence of ATP. (a) Effect of decrease fam-labeled ds DNA substrate after inteaction with Rep34 protein associed helicase activity. Helicase reactions were incubated at $37^{\circ} \mathrm{C}$ for $30 \mathrm{~min}$ and the substrate and product were quantified by fluorometric analysis. (b) Unwinding super coiled form of plasmid pGP2 by $\mathrm{Rep}_{34}$ helicase activity. Lane 1 standard plasmid pGP2, lane 2-8 activity measured after every 10 minutes of incubation with rep34 protein in optimal reaction condition (OC - open circular, SC - super coiled form).

the protein, using the cleavage of synthetic substrate p-nitrophenyl phosphate. The $\operatorname{Rep}_{34}$ was able to cleave pNPP in the presence and in the absence of $\mathrm{Mg}^{2+}$ ions (Figure 5). Enzyme activity is higher about $20 \%$ in the presence than absence $\mathrm{Mg}^{2+}$ ions. However phosphatase activity of this protein is about hundred times lower than is described in bacterial acid phosphatases [43]. Assuming a Michaelis-Menten model of the enzymatic activity, we used Lineweaver-Burk plots to derive catalytic parameters $\mathrm{K}_{\mathrm{m}}$ and $\mathrm{V}_{\max }$. The $\mathrm{K}_{\mathrm{m}}$ value calculated in the presence of $\mathrm{Mg}^{2+}$ for $\mathrm{Rep}_{34}$ is $0.46 \pm 0.01 \mathrm{mM}$ and in the absence of $\mathrm{Mg}^{2+}$ is $1.09 \pm 0.01$. The phospthatase activeity is lower than described in bacterial $\mathrm{C}$ acid phosphatase of Helicobacter pylori $(1.20 \pm 0.25 \mathrm{mM})$ [44].

\subsection{Helicase Assay}

To demonstrate DNA helicase activity, unwinding was monitored by the release of a Fam-labeled 32-mer from a partially double-stranded circular M13 DNA substrate. The release labeled primer from double strand DNA was separated by ethanol precipitation. The pellet was dissolved in water and used for quantification on a fluorescent reader (Figure 6(a)). Unwinding activity Rep 34 protein showed continuously decrease labeled dsDNA after $30 \mathrm{~min}$ incubation at $37^{\circ} \mathrm{C}$ with $0.5 \mu \mathrm{g}$ of protein (Figure 6(b)). Although a concentration-dependent increase in helicase activity was observed at lower protein concentrations, the amount of unwinding was not significantly increased at greater than $0.5 \mu \mathrm{g}$ of protein (data not shown).

Finally, new replication protein from plasmid isolated from Acetobacter strain was cloned and exprimed in $E$. coli expression systems. Small protein with basic isoelectric point has two domains one for interaction with other replication protein with leucine zipper and second HTH domain for interaction with DNA. Purified replication protein has phosphatase activity, ATP-ase activity and is able to unwind double strand DNA molecule. HTH domain specific recognise boundig region for iniciation replication and transcription of plasmid pGP2. Fusion of this replication protein with GFP protein was used to monitor protein expression by fluorometric microscopy.

\section{REFERENCES}

[1] Konieczny, I. (2003) Strategies for helicase recruitment and loading in bacteria. EMBO Report, 4(1), 37-41.

[2] Messer, W. (2002) The bacterial replication initiator DnaA. DnaA and oriC, the bacterial mode to initiate DNA replication. FEMS Microbiology Review, 26(4), 355-374.

[3] Messer, W. and Weigel, C. (2003) DnaA as a transcripttion regulator. Methods in Enzymology, 370, 338-349.

[4] Mackiewicz, P., Zakrzewska-Czerwinska, J., Zawilak, A., Dudek, M.R. and Cebrat, S. (2004) Where does bacterial replication start? Rules for predicting the oriC region. Nucleic Acids Research 32(13), 3781-3791.

[5] Schmidhauser, T.J., Filutowicz, M. and Helinski, D.R. (1983) Replication of derivatives of the broad host range plasmid RK2 in two distantly related bacteria. Plasmid, 9(3), 325-330.

[6] Shah, D.S., Cross, M.A., Porter, D., Thomas, C.M. (1995) Dissection of the core and auxiliary sequences in the vegetative replication origin of promiscuous plasmid RK2. Journal of Molecular Biology, 254(4), 608-622.

[7] Doran, K.S., Helinski, D.R. and Konieczny, I. (1999) Host-dependent requirement for specific DnaA boxes for plasmid RK2 replication. Molecular Microbiology, 33(3), 490-498.

[8] Kawasaki, Y., Matsunaga, F., Kano, Y., Yura, T. and Wada, C. (1996) The localized melting of mini-F origin by the combined action of the mini-F initiator protein (RepE) and HU and DnaA of Escherichia coli. Molecular 
and General Genetic, 253(1-2), 42-49.

[9] Lu, Y.B., Datta, H.J. and Bastia D. (1998) Mechanistic studies of initiator-initiator interaction and replication initiation. EMBO Journal, 17(17), 5192-5200.

[10] Park, K., Mukhopadhyay, S. and Chattoraj, D.K. (1998) Requirements for and regulation of origin opening of plasmid P1. Journal of Biological Chemistry, 273(38), 24906-24911.

[11] Kruger, R., Konieczny, I. and Filutowicz, M. (2001) Monomer/dimer ratios of replication protein modulate the DNA strand-opening in a replication origin. Journal of Molecular Bioliology, 306(5), 945-955.

[12] Sharma, R., Kachroo, A. and Bastia, D. (2001) Mechanistic aspects of DnaA-RepA interaction as revealed by yeast forward and reverse twohybrid analysis. $E M B O$ Journal, 20(16), 4577-4587.

[13] Konieczny, I. and Helinski, D.R. (1997) Helicase delivery and activation by DnaA and TrfA proteins during the initiation of replication of the broad host range plasmid RK2. Journal of Biological Chemistry, 272(52), 33312-33318.

[14] Doran, K.S., Konieczny, I. and Helinski, D.R. (1998) Replication origin of the broad host range plasmid RK2: positioning of various motifs is critical for initiation of replication. Journal of Biological Chemistry, 273(14), 8447-8453.

[15] Sharma, R., Kachroo, A. and Bastia, D. (2001) Mechanistic aspects of DnaA-RepA interaction as revealed by yeast forward and reverse twohybrid analysis. $E M B O$ Journal, 20(16), 4577-4587.

[16] Kues, U. and Stahl, U. (1989) Replication of plasmids in gram-negative bacteria. Microbiology Review, 53(4), 332-343.

[17] del Solar, G., Giraldo, R., Ruiz-Echevarria, M.J., Espinosa, M. and Diaz-Orejas, R. (1998) Replication and control of circular bacterial plasmids. Microbiology Molecular Biology Review, 62(2), 434-464.

[18] Okumura, H., Uozumi, T. and Beppu, T. (1985) Construction of plasmid vectors and genetic transformation system for Acetobacter aceti. Agricultural and Biological Chemistry, 49(4), 1011-1017.

[19] Fukaya, M., Okumura, T., Masai, H., Uozumi, T. and Beppu, T. (1985) Construction of new shuttle vector for Acetobacte. Agricultural and Biological Chemistry, 49(7), 2083-2090.

[20] Grones, J., Škereňová, M., Bederková, K. and Turňa, J. (1989) Isolation and characterisation of plasmid pAC1 from Acetobacter pasteurianus. Biologia, 44(12), 1181-1186.

[21] Fomenkov, A., Xiao, J. and Xu, S. (1995) Nucleotide sequence of a small plasmid isolated from Acetobacter pasteurianus. Gene, 158(1), 143-144.

[22] Trček, J., Raspor, P. and Teuber, M. (2000) Molecular identification of Acetobacter isolates from submerged vinegar production, sequence analysis of plasmid pJK2-1 and application in the development of a cloning vector. Applied. Microbiology and Biotechnology, 53(3), 289-295.

[23] Kretová, M., Szemes, T., Laco, J., Gronesová, P. and Grones, J. (2005) Analysis of replication region of the cryptic plasmid pAG20 from Acetobacter aceti 3620. Biochemical and Biophysical Research Commununica- tion, 328(1), 27-31.

[24] Bullock, W.O., Fernandez, J.M. and Short J.M. (1987) XL1-Blue - a high-efficiency plasmid transforming recA Escherichia coli strain with $\beta$-galactosidase selection, Biotechniques 5(3), 376-379.

[25] Sanger, F., Nicklen, S. and Coulson, A.R. (1977) DNA sequencing with chainterminating inhibitors, Proceedings of the National Academy of Sciences of the U.S.A., 74(12), 5463-5467.

[26] Altschul, S.F., Madden, T.L., Schaffer, A.A., Zhang, J., Zhang, Z., Miller, W. and Lipman, D.J. (1997) Gapped BLAST and PSI-BLAST: a new generation of protein database search Programs. Nucleic Acids Research, 25(17), 3389-3402.

[27] Thompson, J.D., Higgins, D.G. and Gibson, T.J. (1994) CLUSTALW: improving the sensitivity of progressive multiple sequence alignment through sequence weighting, position-specific gap penalties and weight matrix choice. Nucleic Acids Research, 22(22), 4673-4680.

[28] Cuff, J.A., Clamp, M.E., Siddiqui, A.S., Finlay, M. and Barton, G.J. (1998) Jpred: a consensus secondary structure prediction server. Bioinformatics, 14(10), 892-893.

[29] Rost, B., Yachdav, G. and Liu, J. (2004) The PredictProtein Server. Nucleic Acids Research, 32, W321-W326.

[30] Bryson, K., McGuffin, L.J., Marsden, R.L., Ward, J.J., Sodhi, J.S. and Jones, D.T. (2005) Protein structure prediction servers at University College London. Nucleic Acids Research, 33, W36-W38.

[31] Cheng, J., Randall, A., Sweredoski, M. and Baldi, P. SCRATCH: a protein structure and structural feature prediction server. Nucleic Acids Research, 33, W72-W76.

[32] Lanzetta, P.A., Alvarez, L.J., Reinach, P.S. and Candia, O.A. (1979) An improved assay for nanomole amounts of inorganic phosphate. Analytical Biochemistry, 100(1), 95-97.

[33] Matson, S.W., Tabor, S. and Richardson, C.C. (1983) The gene 4 protein of bacteriophage T7: Characterization of helicase activity. Journal of Biological Chemistry, 258(22), 14017-14024.

[34] Wiley, S.R., Kraus, R.J. and Mertz, J.E. (1992) Functional binding of the TATA box binding component of transcription factor TFIID to the -30 region of TATA-less promoters. Proceedings of the National Academy of Sciences of the U.S.A., 89(13), 5814-5818.

[35] Sambrook, J., Fritsch, E.F. and Maniatis, T. (1989) Molecular Cloning: A Laboratory Manual. Cold Spring Harbor Laboratory Press, Cold Spring Harbor, NY.

[36] Kamenski, T., Heilmeier, S., Meinhart, A. and Cramer, P. (2004) Structure and mechanism of RNA polymerase II CTD phosphatase. Molecular Cell, 15(3), 399-407.

[37] Laemmli, U.K. (1970) Cleavage of structural proteins during the assembly of the head of bacteriophage T7. Nature, 227(5259), 680-685.

[38] Bradford, M.M. (1976) A rapid and sensitive for the quantitation of microgram quantitites of protein utilizing the principle of protein-dye binding, Analytical Biochemistry, 72, 248-254.

[39] Scherzinger, E., Haring, V., Lurz, R. and Otto, S. (1991) Plasmid RSF1010 DNA replication in vitro promoted by purified RSF1010 RepA, RepB and RepC proteins. Nucleic Acids Research, 19(6), 1203-1211.

[40] Robson, A., Gold, V.A., Hodson, S., Clarke, A.R. and 
Collinson, I. (2009) Energy transduction in protein transport and the ATP hydrolytic cycle of SecA. Proceedings of the National Academy of Sciences of the U.S.A., 106(13), 5111-5116.

[41] Scott, J.F. and Kornberg, A. (1978) Purification of the rep protein of Escherichia coli. Journal of Biological Chemistry, 253(9), 2392-2397.

[42] Ebisuzaki, K., Behme, M.T., Senior, C., Shannon, D. and Dunn, D. (1972) An Alternative Approach to the Study of New Enzymatic Reactions Involving DNA (DNA-dependent ATPases-purification-properties-E. coli). Pro- ceedings of the National Academy of Sciences of the U.S.A., 69(2), 515-519.

[43] Reilly, T.J., Chance, D.L., Calcutt, M.J., Tanner, J.J., Felts, R.L., Waller, S.C., Henzl, M.T., Mawhinney, T.P., Ganjam, I.K. and Fales, W.H., (2009) Characterization of a Unique Class C Acid Phosphatase from Clostridium perfringens. Applied of Environmental Microbiology, 75(11), 3745-3754.

[44] Reillya, T.J. and Calcuttb, M.J. (2004) The class C acid phosphatase of Helicobacter pylori is a 50 nucleotidase. Protein Expression and Purification, 33(1), 48-56. 